\title{
OBITUARY: IN MEMORY OF EDDIE PELTENBURG
}

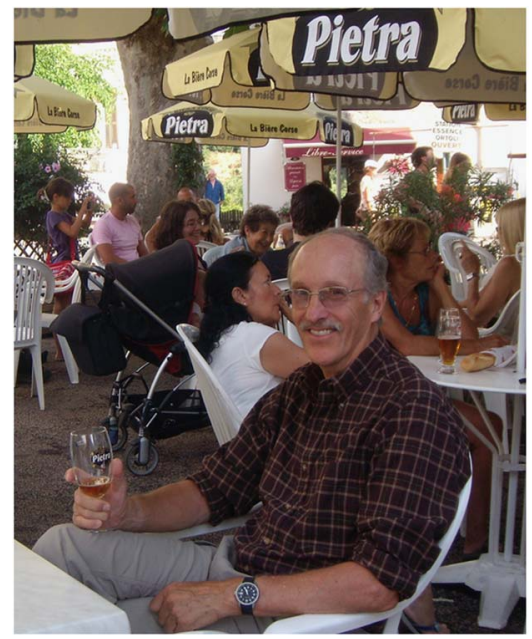

These Proceedings are dedicated to the memory of Professor Edgar Peltenburg, Eddie to all his friends. Eddie was part of the Scientific Committee but fell ill prior to the meeting and was unable to attend. He died early on the 14th August 2016 after a short but difficult struggle with bone marrow cancer. Eddie has been a personal friend and great supporter of the SUERC Radiocarbon Dating Laboratory for many years and we were all greatly saddened by his death.

Eddie was born in Montreal, Canada in 1942 and after moving to the UK, he undertook his higher education at the University of Birmingham where in 1963, he graduated with a BA in Ancient History and Archaeology. He followed this up with a $\mathrm{PhD}$ in Archaeology in 1968. During his early career, Eddie taught at McGill University in Montreal (1963-64), before moving back to the University of Birmingham (1965-69) as a Research Fellow and then to the University of Glasgow (1969-78) as a Lecturer in Archaeology and Resident Staff Tutor for Argyll and Bute. As outreach tutor, he became heavily involved with the local archaeology societies in the west of Scotland where he was responsible for initiating several projects researching the Iron Age of that part of Scotland, most notably Balloch Hillfort and Kildonan dun, both in the vicinity of Campbeltown, SW Scotland. Eddie is still fondly remembered in Argyll by the many friends and neighbours who worked with him on these projects and who benefitted from his teaching as Glasgow's resident outreach tutor.

In 1978, Eddie was appointed to a lecturing post in Near Eastern Archaeology at the University of Edinburgh where he remained for the rest of his academic career. This position allowed him to develop his Near Eastern research interests and to expand his career as a teacher of Near Eastern archaeology. Eddie was appointed as a Professor of Archaeology in 1994 in recognition of his contribution to our understanding of the prehistory of Cyprus and the Near East. He retired in 2007 but remained an active researcher, returning to Cyprus for extended periods twice a year where I regularly met with him and his wife, Diane, for a meal, and conversation about the limitations of dating bone from many sites in the region. Eddie was great company and his enthusiasm for his subject was infectious, however, he was equally enthusiastic as a 


\section{xii Obituary}

listener to my ideas regarding my own areas of research, and that was part of his great charmhe always had time to listen to others.

Commemorative sessions for Eddie are being planned for next year's British Association for Near Eastern Archaeology in Durham (March 2018) and at the University of Cyprus in Nicosia. His memory lives on!

Gordon Cook

Conference Chairman 